In the present study the human monoblast cell line U937 has been used as a model to study the function of human mononuclear phagocytes in asthma. The kinetics of the production of eicosanoids and cytokines, which are thought to play a role in the pathogenes is of asth $m$ a, were studied. In addition, the effects of glucocorticosteroids were investigated, as these drugs are of great importance for the treatment of asth $m$ atic patients. After stimulation with phorbol12 myristate acetate (PMA) for $24 \mathrm{~h}$, U937 cells were cultured in the absence or presence of lipopolysaccharide (LPS: 1 and $5 \mu \mathrm{g} \mathrm{ml}^{-1}$ ) and glucocorticosteroids (budesonide, fluticasone propionate and prednisolone: $10^{-11}, 10^{-9}$ and $\left.10^{-7} \mathrm{M}\right)$ for $96 \mathrm{~h}$. The production of in terleukin- $1 \beta$ (IL-1 $\beta$ ), in terleukin-6 (IL-6), prostaglandin $E_{2}\left(P E_{2}\right)$ and thromboxane $B_{2}$ $\left(T \times B_{2}\right)$ gradually increased in time after stimulation with LPS, whereas the transient production of tumor necrosis factor alpha (TNF- $\alpha$ ) reached its maximum between 6 and $12 \mathrm{~h}$. In terferon-gam ma (IFN- $\gamma)$, interleukin-10 (IL-10) and leukotriene $B_{4}\left(\right.$ LTB $\left._{4}\right)$ were not detectable. All three glucocorticosteroids (budesonide, fluticasone propionate and prednisolone) com pletely inhibited the production of both eicosanoids and cytokines. The production of eicosanoids was more sensitive to these glucocorticoids than the production of cytokines. The observed differences in the kinetics of the production of eicosanoids and cytokines stress the importance of time course experiments in studies on the effect of drugs on mononuclear cells.

Key words: Glucocorticosteroids, Cytokines, Arachidonic acid metabolites, U937

\section{Time dependent production of cytokines and eicosanoids by human monocytic leukaemia U937 cells; effects of glucocorticosteroids}

\author{
Ingrid M. Garrelds ${ }^{1,2, \mathrm{CA}}$, Peter Th. W. van $\mathrm{Hal}^{2}$, \\ Raquel C. Haakmat ${ }^{1}$, Henk C. Hoogsteden ${ }^{2}$, \\ Pramod R. Saxena ${ }^{1}$ and Frederik J. Zijlstra ${ }^{1}$
}

${ }^{1}$ Institute of Pharmacology, Faculty of Medicine, Erasmus University Rotterdam, PO Box 1738, 3000 DR Rotterdam and ${ }^{2}$ Department of Pulmonary Medicine, University Hospital Rotterdam-Dijkzigt,The Netherlands

\footnotetext{
${ }^{\mathrm{CA}}$ Corresponding Author

Institute of Pharmacology, Erasmus University

Rotterdam, PO Box 1738, 3000 DR Rotterdam, The

Netherlands

Tel: $(+31) 104087534$

Fax: (+31) 104089458

Email: Garrelds@farma.fgg.eur.nl
}

\section{Introduction}

Inflammation of the airw ays underlies a major part of the clinical symptoms in asthma and chronic obstructive pulmonary diseases (COPD). A number of studies support the involvement of mononuclear phagocytes in asthma. ${ }^{1-3}$ Alveolar macrophages phagocytose inhaled particles and antigens, but as inflammatory cells they are know $n$ to produce potent inflammatory mediators, including proteins and lipids mediators, which are able to influence other cell types.

Several features of asthma can be mimicked in vitro and in vivo by these secretory products. ${ }^{4}$ We and others have previously show $\mathrm{n}$ that prostaglandin $\mathrm{D}_{2}$, prostaglandin $\mathrm{F}_{2 \alpha}$ and a stable analogue of thromboxane $A_{2}$ all constric thuman airw ay muscle. ${ }^{5}$ Le uko trie ne $\mathrm{B}_{4}\left(\mathrm{LTB}_{4}\right)$ increases vascular permeability and enhances adherence and migration of granulocytes. Inhalation of $\mathrm{LTB}_{4}$ results in peripheral ne utropenia and the accumulation of leucocytes in the airway wall. ${ }^{6}$ Leukotrie ne $\mathrm{C}_{4}\left(\mathrm{LTC}_{4}\right)$ induces bronchoconstriction, reduces the clearance of mucus and increases vascular permeability. ${ }^{7}$ Cytokines, such as IL- $1 \beta$, IL- 6 and TNF- $\alpha$, play an important role in immune reactions and regulate the grow th and state of activity of many cells in inflammation including the airway inflammation present in asthma. ${ }^{8}$ Both eicosanoids and cytokines can also be released from inflammatory cells in culture. Some studies have investigated the regulation of cytokines and eicosanoids in macrophage cell lines or macrophages stimulated with various inflammatory agents. ${ }^{9-13}$

The human monoblastoid U937 tumour cell line is widely used as a model for the maturation of monocytic cells. ${ }^{14}$ U937 is an established human monoblast cell line derived from the pleural exudate of a patient with diffuse histiocytic lymphoma. Maturation of U937 can be induced by incubation with different agents, including retinoic acid, ${ }^{15}$ vitamin D derivative $s,{ }^{16}$ cytokines ${ }^{17}$ and phorbol esters. ${ }^{18}$ Phorbol ester-induced maturation results in cessation of proliferation and significant alterations in the morphology of the cells. Under standard conditions, U937 cells grow in suspension and exhibit a smooth 
and round surface, but they become adherent, start to form cell clusters and extend pseudopodia upon phorbol ester treatment. ${ }^{18-20}$ The morphological changes observed during this maturation process suggest functional changes of the U937 cells.

We studied the kinetics of the production of several cytokines, IL-1 $\beta$, IL- 6 , IL-10, IFN- $\gamma$ and TNF- $\alpha$ and eicosanoids $\mathrm{PGE}_{2}, \mathrm{Tx}_{2}$ and $\mathrm{LTB}_{4}$ in $\mathrm{U} 937$ to clarify whether mediators are sequentially released by activated mononuclear cells. These mediators were studied, because they are thought to be of importance in the pathogenesis of the airway inflammation in lung diseases. Furthermore, the effectiveness of glucocorticosteroids to suppress the formation of inflammatory mediators was investigated. We used budesonide, fluticasone propionate and prednisolone, because they are the most important drugs currently used in the treatment of asthma.

\section{Materials and methods}

\section{Cell culture}

U937 cells (American Type Culture Collection USA, batch 1593.2) were cultured in RPMI 1640 medium (Gibco, UK) supplemented with penicillin (ICN, USA; $100 \mu \mathrm{g} \mathrm{ml}^{-1}$ ), strep tomycin (ICN, USA; $100 \mu \mathrm{g} \mathrm{ml}^{-1}$ ), glutamax-I (Gibco, UK; $10 \mathrm{mM}$ ) and $10 \%$ foetal bovine serum (FBS; Gibco, UK) in tissue culture flasks (Costar, UK) at $37^{\circ} \mathrm{C}$ humidified atmosphere with $5 \%$ carbon dioxide.

Maturation of U937 cells was induced with $250 \mathrm{ng}$ $\mathrm{ml}^{-1}$ PMA (Sigma, USA). Cells were cultured for $24 \mathrm{~h}$ with PMA and further grown for $48 \mathrm{~h}$ in fresh complete medium. Cell viability was assessed by trypan-blue exclusion in the non-adherent untreated U937 as well as in the PMA treated U937 cells. The viability of the cells was $>95 \%$

The adherent cells were scraped from the tissue culture flasks with a rubber policeman and aliquots of $0.5 \times 10^{6}$ cells in $1 \mathrm{ml}$ were put in $24 \mathrm{wells}$ plastic multiwell culture plates (Costar, UK) and incubated with $1 \mu \mathrm{g} \mathrm{m}^{-1}$ or $5 \mu \mathrm{g} \mathrm{ml}^{-1}$ or without LPS from Escherichia coli (Serotype 0111:B4; Sigma, USA). The cells were incubated for $1,3,6,8,10,12,24,48$ and $96 \mathrm{~h}$ in separate wells at $37^{\circ} \mathrm{C}$. Cell-free supernatants were collected and stored at $-80^{\circ} \mathrm{C}$ until measurements of lipid mediators and cytokines.

\section{Incubation with steroids}

To ensure that the U937 cell line in our investigations could be used to evaluate glucocorticoid responsiveness, we performed the experiment with steroids. We used three corticosteroids, namely budesonide (Sigma, USA), fluticasone propionate (gift of Glaxo Wellcome, UK) and prednisolone sodium phosphate (Genfarma, NL). The drugs were used in the final concentrations: $10^{-11}, 10^{-9}$ and $10^{-7} \mathrm{M}$.
The cells were pre-treated with PMA, the drugs were added to the cell cultures $24 \mathrm{~h}$ prior to stimulation with LPS. From this set point $[t=0]$ the cells were incubated for $1,3,6,8,10,12,24,48$ and $96 \mathrm{~h}$ in the presence or absence of the drug and/or LPS. The cell-free supernatants were stored at $-80^{\circ} \mathrm{C}$ until measurements.

Cell viability was not altered after drug treatment.

\section{Measurements of cytokines}

IL-1 $\beta$ (R\&D systems, USA), IL-6 (CLB, NL), IL-10 (Pharming, USA), TNF- $\alpha$ (Pharming, USA) and IFN- $\gamma$ (Medgenix, Belgium) levels were measured using enzyme- linked immunosorbent assay (ELISA).

\section{Measurements of eicosanoids}

The supernatants were processed as described in detail previously with slight modifications. ${ }^{21}$ SepPak $\mathrm{C}_{18}$ cartridges (Waters Ass., USA) we re activated with $10 \mathrm{ml}$ of methanol pre-washed with $10 \mathrm{ml}$ distilled water. Two hundred and fifty $\mu 1$ of supernatant was applied to the columns and rinsed with $2.5 \mathrm{ml}$ methanol, dried with a Savant Speed-Vac concentrator, and dissolved in $1 \mathrm{ml}$ radioimmunoassay (RIA) buffer. $\mathrm{PGE}_{2}$ and $\mathrm{Tx}_{2}$ production were measured by RIA (antibodies were obtained from PerSeptive Diagnostics, USA, tritiated antigens from Amersham, UK and standards from Sigma, USA). $\mathrm{LTB}_{4}$ levels were measured by enzyme immuno assay (EIA) kits, which were obtained from Amersham, USA.

\section{Statistical analysis}

Each drug was studied in four separate experiments and the values are expressed as mean \pm s.e. mean. Statistical comparisons between control and drugtre ated cell cultures were made by ANOVA followed by paired $t$-test. A $p<0.05 \mathrm{w}$ as conside red signific ant.

\section{Results}

\section{LPS-induced cytokine production after pre-treatment with PMA}

In standard medium without PMA, U937 cells had a smooth and round surface and did not produce the cytokines and eicosanoids studied (data not shown). After addition of PMA they became adherent by forming cell clusters, extended pseudopodia and, as show $n$ in Fig. 1, released IL-1 $\beta$, IL-6 and TNF- $\alpha$ in response to LPS stimulation. However, LPS did not induce the PMA-treated cells to produce INF- $\gamma$ or IL-10 (data not shown). After incubation with LPS the amounts of IL-1 $\beta$ increased signific antly at 48 and $96 \mathrm{~h}$, which seemed to be concentration dependent. IL-6 levels already increased significantly after $6 \mathrm{~h}$, after which the levels reached a plateau. TNF- $\alpha$ production 


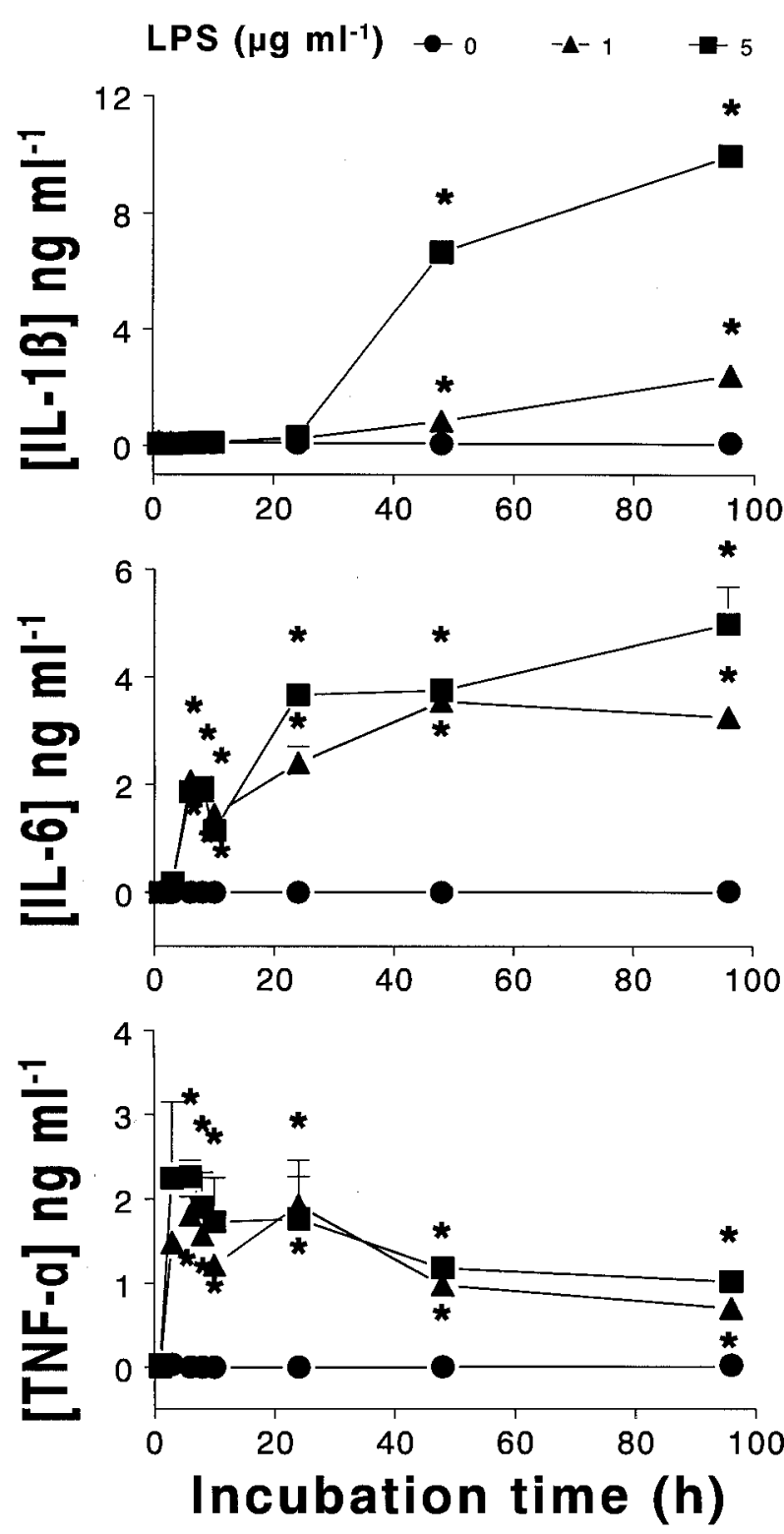

FIG. 1. Kinetics of IL-1 $\beta$ (top panel), IL-6 (middle panel) and TNF- $\alpha$ (lower panel) production in PMA-treated U937 cells which were stimulated with LPS. Data represent mean \pm s.e. mean obtained from four separate experiments. ${ }^{*} p<0.05$ versus response without LPS. When no error bar is visible, error falls within the limit of the symbol.

show ed a different pattern compared with IL-1 $\beta$ and IL6 ; its levels increased after $6 \mathrm{~h}$ of incubation with LPS, but started to decrease after $24 \mathrm{~h}$.

\section{LPS-induced eicosanoid production after pre-treatment with PMA}

We determined the effects of LPS on $\mathrm{PGE}_{2}, \mathrm{Tx}_{2}$ and $\mathrm{LTB}_{4}$ production by $\mathrm{U} 937$ cells which we re pre-treated with PMA. Without PMA, U937 cells did not produce any of the eicosanoids studied (data not shown). The cells primed with PMA released $\mathrm{PGE}_{2}$ and $\mathrm{Tx}_{2} \mathrm{~B}_{2}$, but not $\mathrm{LTB}_{4}$, in response to LPS (Fig. 2). This effect was timerelated. The levels of $\mathrm{Tx}_{2}$ already reached a plateau phase after $6 \mathrm{~h}$, whilst the levels of $\mathrm{PGE}_{2}$ increased slow ly with time.

\section{Effect of glucocorticosteroids on the LPS-induced production of inflammatory mediators by PMA pre-treated U937 cells}

Glucocorticosteroids downregulate the cytokine expression of human alveolar macrophages. ${ }^{22}$ To investigate whether the U937 cells could be used as a model to study glucocorticoid responsiveness in monocytes/macrophages, we incubated the cells with budesonide, fluticasone propionate or prednisolone. Figures 3, 4 and 5 show the data obtained
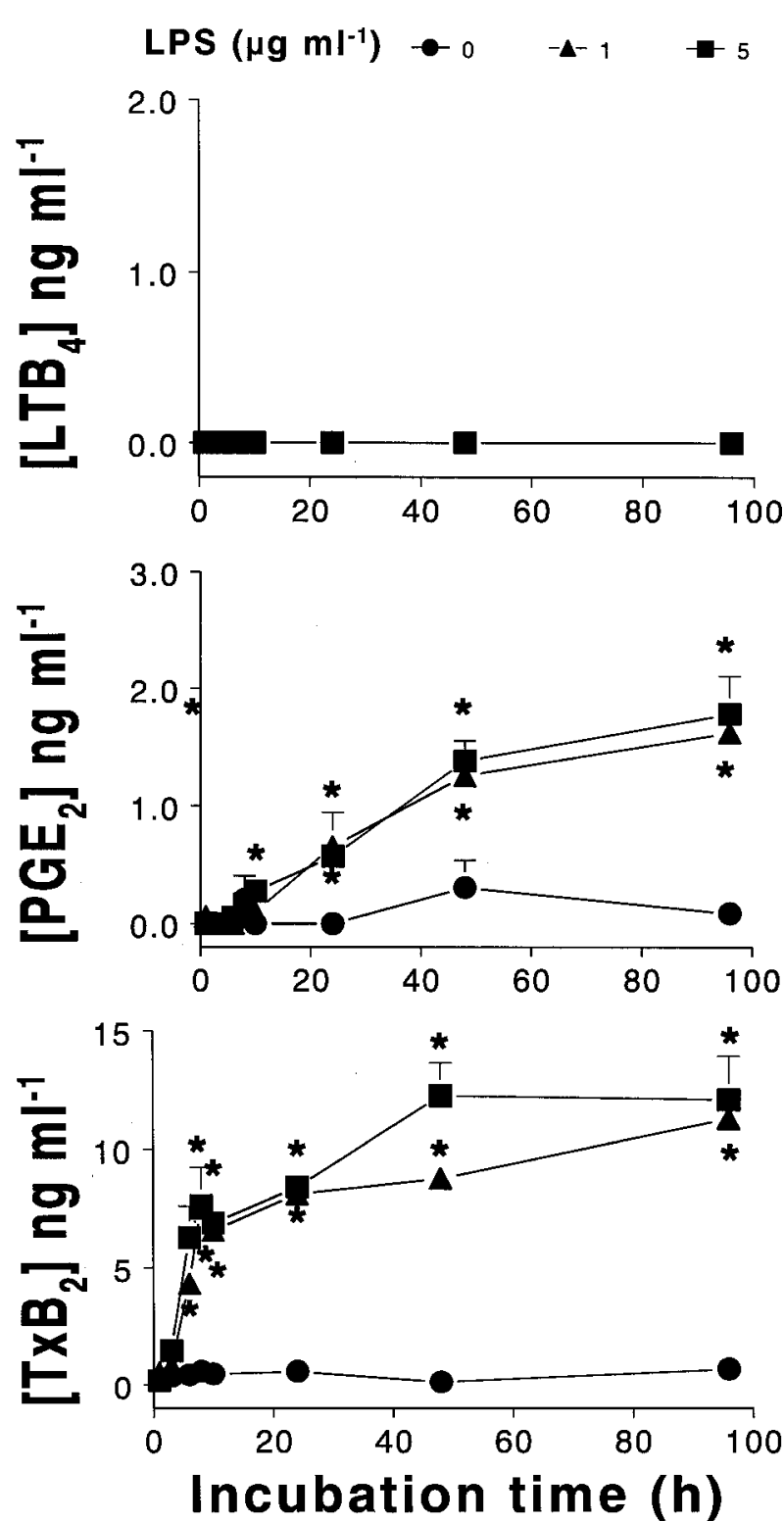

FIG. 2. Kinetics of $\mathrm{LTB}_{4}$ (upper panel), $\mathrm{PGE}_{2}$ (middle panel) and $\mathrm{TxB}_{2}$ (lower panel) production in PMA-treated U937 cells which were stimulated with LPS. Data represent mean \pm s.e. mean obtained from four separate experiments. ${ }^{*} p<0.05$ versus response without LPS. When no error bar is visible, error falls within the limit of the symbol. 
with budesonide, fluticasone proprionate and prednisolone respectively. The production of IL-1 $\beta$ and IL-6 was dose-dependently inhibited by all three steroids. At $10^{-7} \mathrm{M}$ concentration, all three steroids completely abolished the production of IL- $1 \beta$, IL- 6 and TNF- $\alpha$ induced by LPS. In the absence of LPS no production could be found in the supernatant (data not shown). Similarly, the production of the eicosanoids $\left(\mathrm{PGE}_{2}\right.$ and $\left.\mathrm{Tx}_{2}\right)$ was already inhibited by all three glucocorticosteroids at concentrations of $10^{-11} \mathrm{M}$.

\section{Discussion}

In the present study we have shown that PMA induced morphological differentiation of U937 cells. We also found that PMA pre-treated U937 cells needed LPS for the production of both cytokines (IL-1 $\beta$, IL-6 and TNF- $\alpha$ and eicosanoids $\left(\mathrm{PGE}_{2}\right.$ and Tx $\left.\mathrm{B}_{2}\right)$. IL-6 $\mathrm{w}$ as already detectable after $6 \mathrm{~h}$ of incubation, whereas IL$1 \beta$ could be detected after $48 \mathrm{~h}$. The production of both cytokines reached a plateau, in contrast to the transient induction of TNF- $\alpha$ which was maximal between 6 and $24 \mathrm{~h}$. Furthermore, we showed that the production of eicosanoids could be inhibited by lower concentrations of glucocorticoids as compared with the production of cytokines.

Unstimulated U937 cells exhibited a smooth and round surface, but after PMA addition they became adherent by forming cell clusters and extended pseudopodia, which is in agreement with the findings of Hosoya \& Marunouchi. ${ }^{20}$ Unlike these changes in morphology, the production of cytokines and eicosanoids could be induced by LPS and PMA together only. However, Hass et al. ${ }^{23}$ found that U937 cells released IL-1 $\beta$ and TNF- $\alpha$ after TPA tre atme nt w ithout LPS. IL- $1 \alpha$ and IL- 6 could not be detected in their system. The basis of these differences is unclear. A
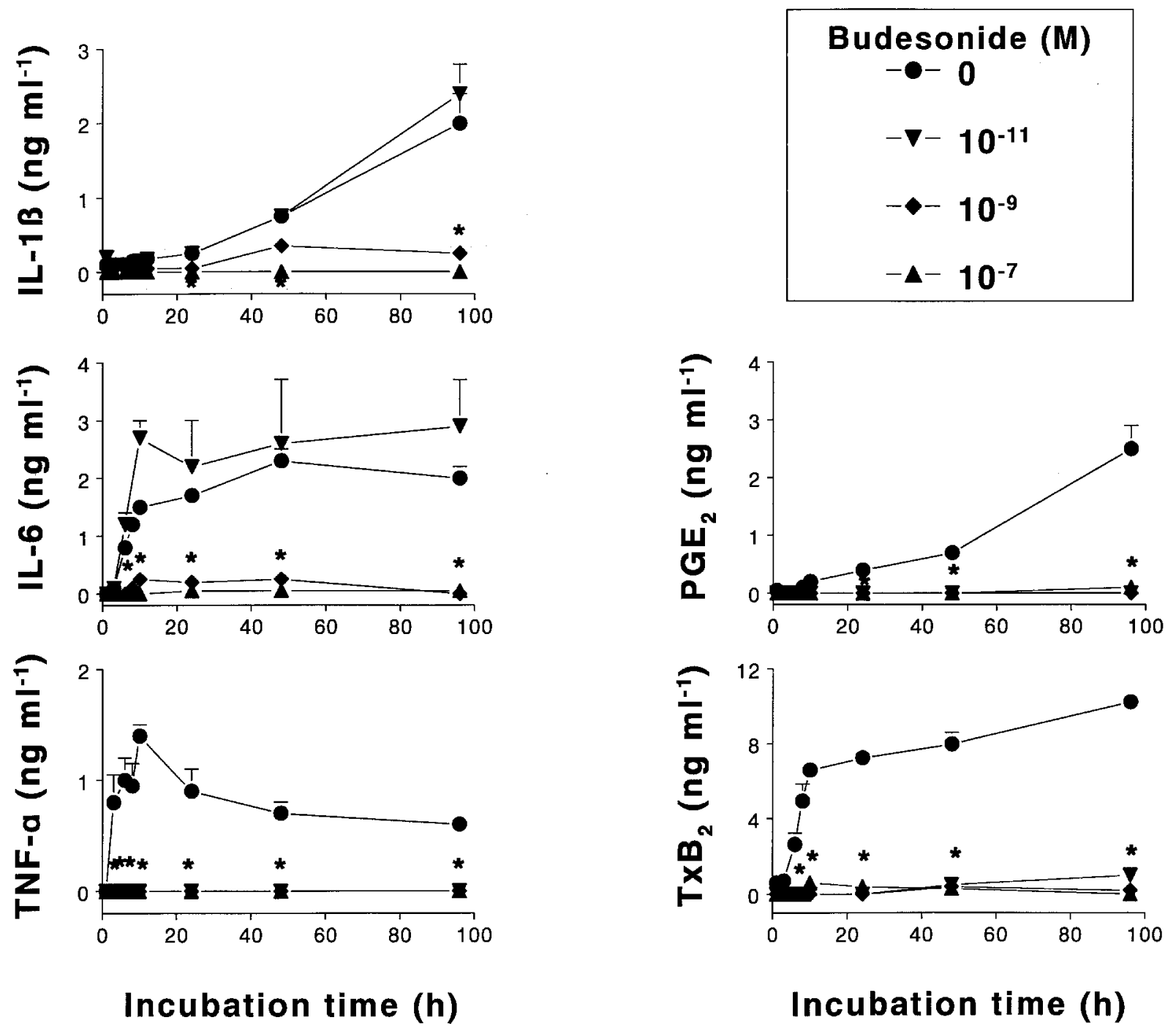

FIG. 3. Effects of budesonide on IL-1 $\beta$, IL-6, TNF- $\alpha, \mathrm{PGE}_{2}$ and $\mathrm{TxB}_{2}$ production by $\mathrm{U} 937$ cells pre-treated and stimulated with PMA and LPS respectively. Data represent mean \pm s.e. mean obtained from four separate experiments. ${ }^{*} p<0.05$ compared with control cultures. When no error bar is visible, error falls within the limit of the symbol. 

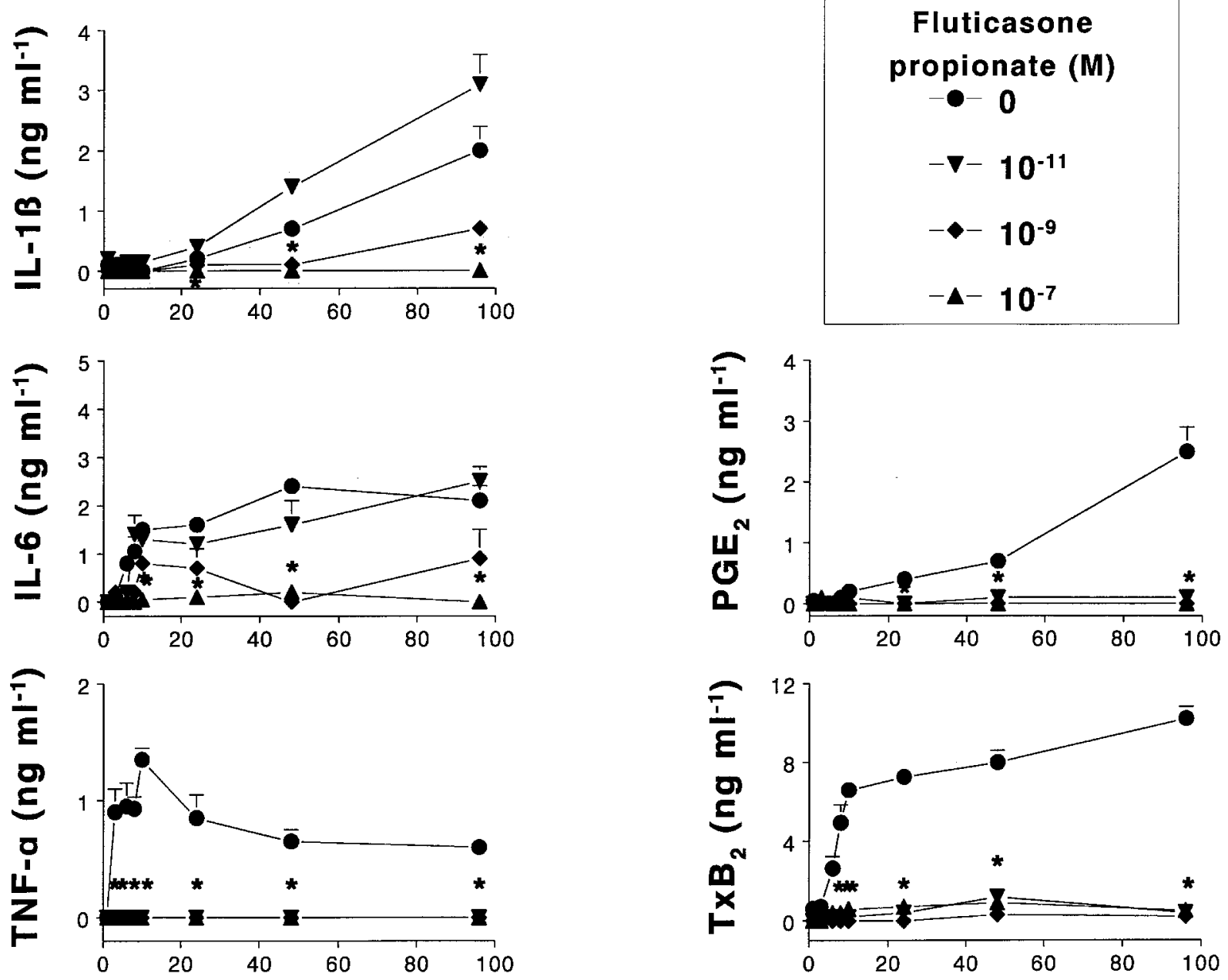

\section{Incubation time (h)}

Incubation time (h)

FIG. 4. Effects of fluticasone propionate on IL-1 $\beta, I L-6, T N F-\alpha, P E_{2}$ and $T_{x B}$ production by U937 cells pre-treated and stimulated with PMA and LPS respectively. Data represent mean \pm s.e. mean obtained from four separate experiments. ${ }^{*} p<0.05$ compared with control cultures. When no error bar is visible, error falls within the limit of the symbol.

possible explanation may be that a subclone of U937 was used different from the one used in our experiments. However, Hass et al. ${ }^{23}$ also showed in their system that TNF- $\alpha$ was ex pressed earlier (alre ady after $2-4 \mathrm{~h}$ ) than IL-1 $\beta$ (after $24-48 \mathrm{~h}$ ), and this difference in kinetics is in agreement with our results.

In this investigation we showed an increase in TNF$\alpha$ production until $12 \mathrm{~h}$ of incubation with LPS. TNF- $\alpha$ is known as a macrophage activator. ${ }^{12}$ Therefore, it can be expected that after $12 \mathrm{~h}$ all the U937 cells present in the well would be activated and thus the production of TNF- $\alpha$ will be terminated. Taimi et a $l^{24}$ observed that IL-6 is produced by PMA-differentiated U937 cells after stimulation with LPS. We showed that the production increased significantly after $6 \mathrm{~h}$ of incubation, after which the levels reached a plateau. This may indicate that at this point the cells have stopped producing IL-6 and that the amount of IL-6 is the actual amount that the cells have produced without any breakdown of IL-6. This plateau could also have been reached because the rate of breakdown of IL-6 equalled the production of IL- 6 . We demonstrate $d$ that the amount of IL-1 $\beta$ secreted by PMA pre-treated U937 gradually increased after incubation with LPS even after 48 and $96 \mathrm{~h}$. Previous studies have show $\mathrm{n}$ that IL-1 generation is dependent on the stage of differentiation. ${ }^{25}$ The basis of the differential and sequential expression of the three cytokines studied here may be caused by sequential secretion or gene expression during PMA/LPSinduced differentiation.

We observed that PMA-treated U937 produced the eicosanoids $\mathrm{PGE}_{2}$ and $\mathrm{TxB}_{2}$, but no $\mathrm{LTB}_{4}$, after incubation with LPS. Since $\mathrm{LTB}_{4}$ was not detectable, the generation of leukotrienes appears to represent a property of cells at a later state in the differentiation along the monocyte/macrophage lineage. Köhler found that $\mathrm{U} 937$ secre ted $\mathrm{PGE}_{2}$ and $\mathrm{Tx}_{2}$, but no $\mathrm{LTB}_{4}$ 
after incubation with TPA and arachidonic acid for $1-24 \mathrm{~h}^{26}$ It is known that human peritoneal macrophages do generate lipoxygenase products after incubation with Ca-ionophore A23187. ${ }^{13}$ How ever, in this study we found no effect of A23187 (1 and $5 \mu \mathrm{M}$ for $15 \mathrm{~min}$ ) on U937 (data not show $\mathrm{n}$ ).

Previous studies have reported the presence of glucocorticoid receptors in U937 cells. ${ }^{27}$ In a recent study we have demonstrated under our culture conditions, using the unadapted receptor assay, specific binding of ${ }^{3} \mathrm{H}$-labelled dexamethasone to these cells. U937 cells appeared to have $17.1+/-5.6 \times$ $10^{3}$ sites per cell and a $K_{d}$ of $5.3+/-1.0 \mathrm{nM}^{28}$ These findings suggested that U937 cells are glucocorticoid responsive. Knudsen has demonstrated that glucocorticosteroids downregulate the IL-1 $\beta$ gene expression by U937, ${ }^{29}$ which has been confirmed in human alveolar macrophages recently. ${ }^{22}$ In this study we confirmed the glucocorticoid-induced dow nregulation of IL-1 $\beta$ in U937 cells, and additionally we showed that also the induction of IL-6 and TNF- $\alpha$ is inhibited by different classes of glucocorticoids. Interestingly, glucocorticoids were able to inhibit the induction of both $\mathrm{PGE}_{2}$ and $\mathrm{TxB}_{2}$ at a much lower concentration $\left(10^{-11} \mathrm{M}\right)$ as compared with the inhibition of the cytokines studied $\left(10^{-7} \mathrm{M}\right)$. This difference may be explained by differences in the underlying working mechanism of glucocorticoids. Glucocorticoids are thought to interfere with the production of eicosanoids via the induction of lipocortins. Lipocortin-1 can be induced in differentiated U937 cells by glucocorticoids. ${ }^{30}$ However, the dow nregulation of cytokine expression by glucocorticoids is thought to occur at the level of either transcription or translation; glucocorticoids may interact with negative glucocorticoid response elements in the gene of some cytokines, may interact with other transcription factors or may decrease the
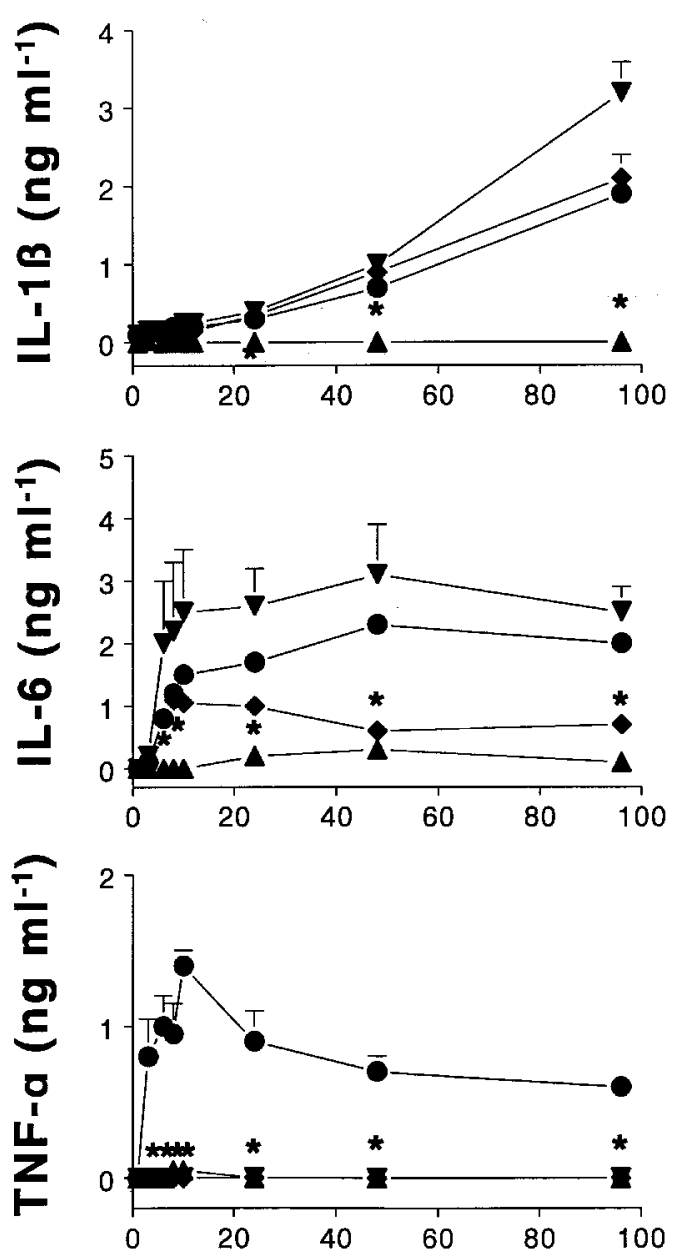

Incubation time (h)
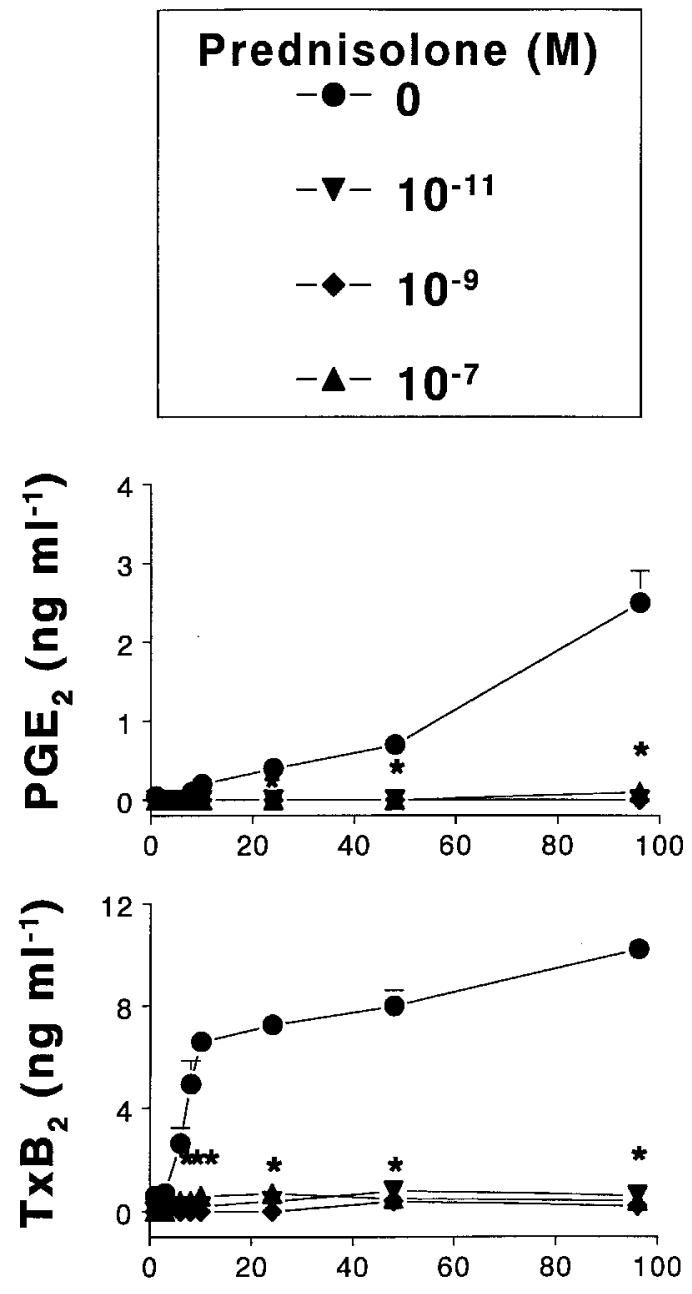

Incubation time (h)

FIG. 5. Effects of prednisolone on IL-1 $\beta$, IL-6, TNF- $\alpha, \mathrm{PGE}_{2}$ and $\mathrm{TxB}_{2}$ production by $\mathrm{U} 937$ cells pre-treated and stimulated with PMA and LPS respectively. Data represent mean \pm s.e. mean obtained from four separate experiments. ${ }^{*} p<0.05$ compared with control cultures. When no error bar is visible, error falls within the limit of the symbol. 
stability of mRNA. ${ }^{31}$ Future studies in U937 should focus on the question, which of these three mechanisms, or combination of mechanisms, underlies the glucocorticoid effects on the cytokine expression observed here.

In conclusion, the results of this study show that U937 cells can be used as a model to study the production of selected inflammatory mediators that are believed to be important in the pathogenesis of asthma. Additionally, U937 cells can be used to study the effects of glucocorticoids on these mediators. The observed differences in the kinetics of the production of eicosanoids and cytokines stress the importance of time course experiments in studies on the effects of drugs on mononuclear phagocytes.

ACKNOWLEDGEMENTS. This investigation was supported by the Netherlands Asthma Foundation (Grant 93.71)

\section{References}

1. Unanue ER, Allen PM. The basis for the immunoregulatory role of macrophages and other accessory cells. Science 1987; 236: 551-557.

2. Van Hal PThW, Overbeek SE, Hoogsteden HC, Zijlstra FJ, Murphy K, OosterhoffY, Postma DS, Guz A, Smith SF Eicosanoids and lipocortin-1 in BAL-fluid in as thma: the effects of smoking and inhaled glucocorticoids. J Appl Physiol 1996; 81: 548-555.

3. SibilleY, Reynolds HY. Macrophages and polymorphonuclear neutrophils in lung defense and injury. Am Rev Respir Dis 1990; 141: 471-501.

4. Wenzel SE. Arachidonic acid metabolites: mediators of inflammation in asthma. Pharmacotherapy 1997; 17: 3S-12S.

5. Zijlstra FJ, Naaktgeboren M. Mons H, Vincent JE. Formation of prostaglandins and leukotrienes by human lung tissue in vitro after activation by the calcium ionophore A23187. Eur J Clin Invest 1987; 17: 325-329.

6. Bray MA. The pharmacology and pathophysiology of leukotriene $\mathrm{B}_{4} . \mathrm{Br}$ Med Bull 1983; 39: 249-255.

7. Dahlén S-E, Kumlin M, Bjorck T, Raud J, Hedqvist J. Leukotrienes and related eicosanoids. Am Rev Respir Dis 1987; 136: S24-28.

8. Virchow JC Jr, Walker C, Hafner D, Kortsik C, Werner P, Matthys H, Kroegel C. T cell and cytokines in bronchoalveolar lavage fluid after segmental allergen provocation in atopic asthma. Am J Respir Crit Care Med 1995; 151: 960-968.

9. Hazuda DJ, Lee JC, Young PR. Differences between interleukin 1 alpha and interleukin 1 beta. J Biol Chem 1988; 263: 8473-8479.

10. Knudsen PJ, Dinarello CA, Strom TB. Prostaglandins posttranscriptionally inhibit monocyte expression of interleukin-1 activity by increasing intracellular cyclic adenosine monophosphate. J Im munol 1986; 137: 3189-3194.

11. Kurt-Jones EA, Virgin HW, Unanue ER. In vivo and in vitro expression of membrane interleukin-1 in response to soluble particulate stimuli. $J$ Imm unol 1987; 137: 10-14.

12. Myers MJ, Pullen JK, Ghildyal N, Eustis-Turf E, Schook LB. Regulation of IL-1 and TNF- $\alpha$ expression during the differentiation of bone marrow derived macrophages. J Im munol 1989; 142: 153-160.

13. Pruimboom WM, Van Dijk APM, Tak CJAM, Bonta IL, Wilson JHP, Zijlstra FJ. Production of inflammatory mediators by human macrophages obtained from ascites. Prost Leukotr Ess Fatty Acids 1994; 50 $183-192$.
14. Sundström C, Nilsson K. Establishment and charac terization of a human histiocytic lymphoma cell line (U-937). Int J Cancer 1976; 17: $565-577$

15. Olsson IL, Breitman TR. Induction of differentiation of the human histiocytic lymphoma cell line U937 by retinoic acid and cyclic adenosine $3^{\prime}: 5^{\prime}$-monophosphate-inducing agents. Cancer Res 1982; 42: 3924-3927.

16. Dodd RC, Cohen MS, Newman, SL, Gray TK. Vitamin D metabolites change the phenotype of monoblastic U937 cells. Proc Natl Acad Sci USA 1983; 80: 7538-7541.

17. Harris PE, Ralph P, Litcofsky P, Moore MAS. Distinct activities of interferon- $\gamma$, lymphokine and cytokine differentiation-inducing factors acting on the human monoblastic leukaemia cell line. Cancer Res 1985; 45: $9-13$.

18. Wiederholt MD, Anderson KM, Harris JE. Labelling of lipids and phospholipids with $\left[{ }^{3} \mathrm{H}\right]$ arachidonic acid and the biosynthesis of eicosanoids in U937 cells differentiated by phorbol ester. Biochem Biophys Acta 1988; 959: 296-304.

19. Hass R, Barthels H, Topley N, Hadam M, Kohler L, Goppelt-Struebe M, Resch K. Regulation of TNF- $\alpha$, IL-1 $\beta$ and IL-6 synthes is in differentiating human monoblastoid leukaemic U937 cells. Eur J Cell Biol 1989; 48: 282-293.

20. Hosoya H, Marunouchi T. Differentiation and dedifferentiation of the human monocytic leukaemia cell line, U937. Cell Struct Funct 1992; 17: 263-269.

21. Zijlstra FJ, Vincent JE, MolWM, Hoogsteden HC, Van Hal PThW, Jongejan RC. Eicosanoid level in bronchoalveolar lavage fluid of young female smokers and non-smokers. Eur J Clin Invest 1992; 22: 301-306.

22. Van Hal PThW, Prins A, Smith SF, Hoogsteden HC. Inverse modulation of lipocortin-1 (annexin-1) and IL-1 $\beta$ gene expression by dexamethasone in cultured human bronchoalveolar macrophages. In: Van Hal, PThW, Human monocytes and alveolar macrophages. Modulation of phenotype and function by cytokines and glucocorticoids in vitro and in asthm a, Ridderkerk.: Ridderprint BV, 1995; 193-208.

23. Hass R, Lonneman G, Mannel D, Topley N, Hartmann A, Kohler L, Resch $\mathrm{K}$, Goppelt-Struebe M. Regulation of TNF- $\alpha$, IL-1 $\beta$ and IL- 6 synthesis in differentiating human monoblastoid leukaemia U937 cells. Leuk Res 1991;15: 327-339.

24. Taimi M, Defacque H, Commes T, Favero J, Caron E, Marti J, Dornand J. Effect of retinoic acid and vitamin D on expression of IL-1 $\beta$, TNF- $\alpha$ and IL-6 in the human monocytic cell-line U937. Imm unology 1993; 73: $229-235$.

25. Carinc V, Guida S, Fontana MR, Palla E, Rossini M, Melli M. Processing of IL-1 in cells of monocytic lineage is differentiation dependent. Eur $J$ Biochem 1992; 205: 295-301.

26. Köhler L, Hass R, Wessel K, Dewitt DL, Kaever V, Resch K, GoppeltStruebe M. Altered arachidonic acid metabolism during differentiatiation of the human monoblastoid cell line U937. Biochim Biophys Act 1990; 1042: 395-403.

27. Kontula K, Andersson LC, Paavonen T, Myllyla G, Teerenhovi L, Vuopio P. Glucocorticoid receptors and glucocorticoid sensitivity of human leukaemic cell. Int J Cancer 1980; 26: 177-183.

28. Van Hal PThW, Mulder E, Hoogsteden HC, Hilvering C, Benner R. Glucocorticoid receptors in alveolar macrophages: methodological aspects of the determination of the number of glucocorticoid receptors per cell. Agents Actions 1989; 26: 128-131.

29. Knudsen PJ, Dinarello CA, Strom TB. Glucocorticoids inhibit transcriptional and post-transcriptional expression of interleukin-1 in U937 cells. J Imm unol 1987; 139: 4129-4134.

30. Solito E, Raugei G, Melli M, Parente L. Dexamethasone induces the expression of the mRNA of lipocortin 1 and 2 and the release of lipocortin 1 and 5 in differentiated, but not undifferentiated U937 cells. FEBS Lett 1991; 291: 238-244.

31. De Waal RMW. The anti-inflammatory activity of glucocorticoids. Mol Biol Rep 1994; 19: 8188 .

\section{Received 16 September 1999; accepted 8 October 1999}




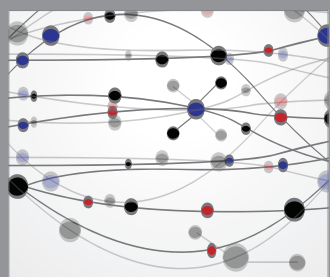

The Scientific World Journal
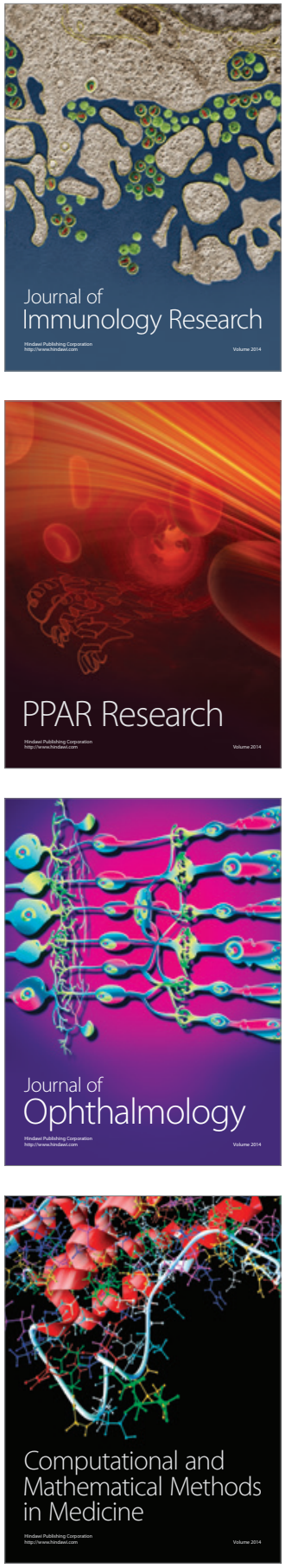

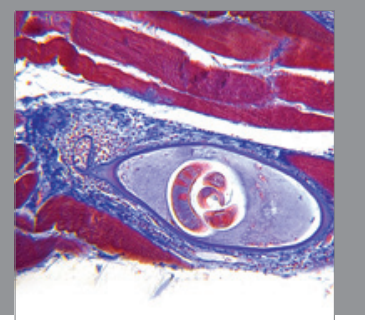

Gastroenterology

Research and Practice
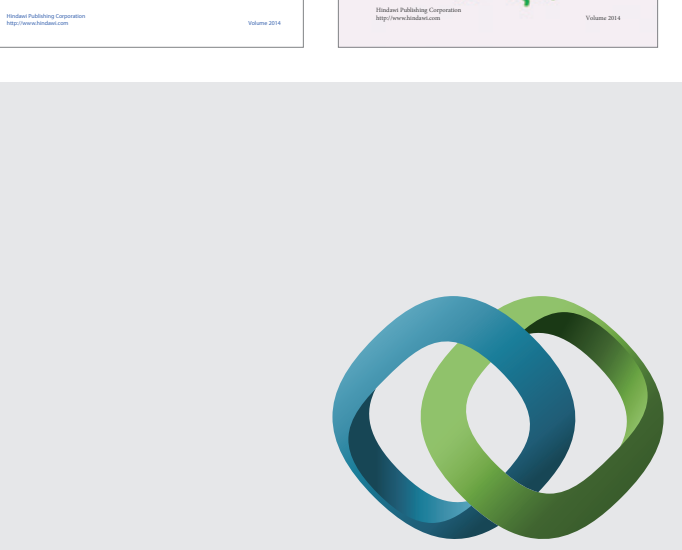

\section{Hindawi}

Submit your manuscripts at

http://www.hindawi.com
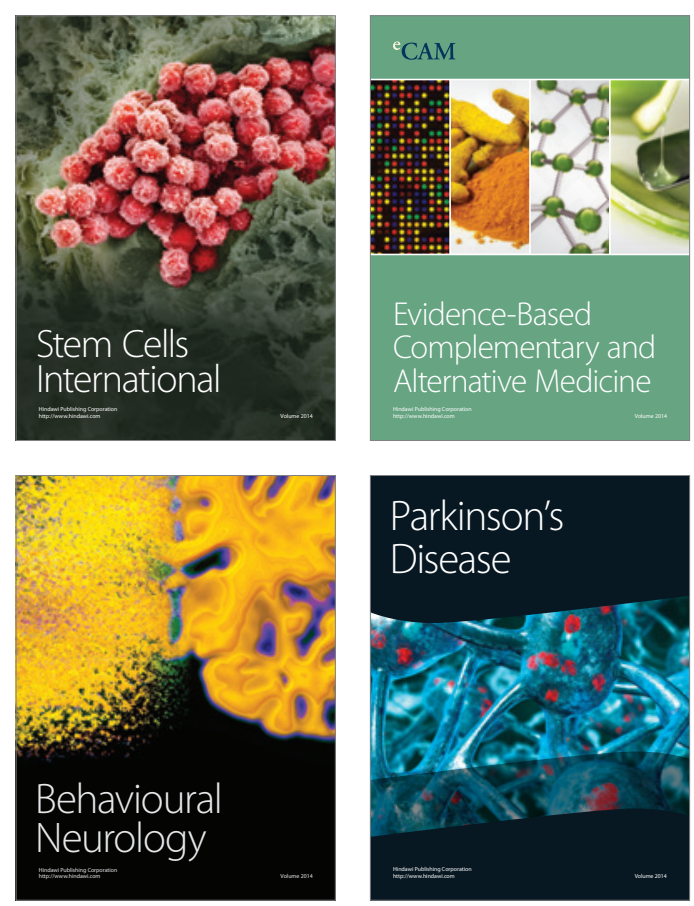

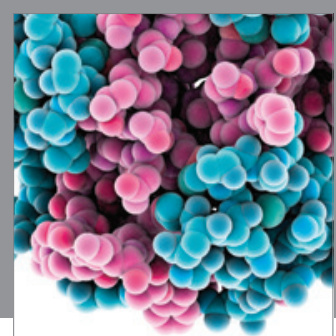

Journal of
Diabetes Research

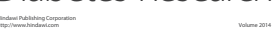

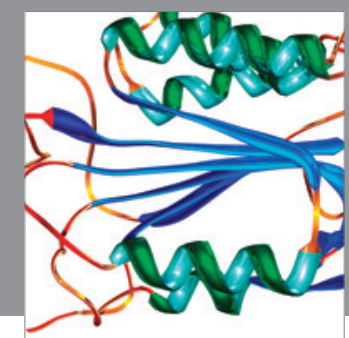

Disease Markers
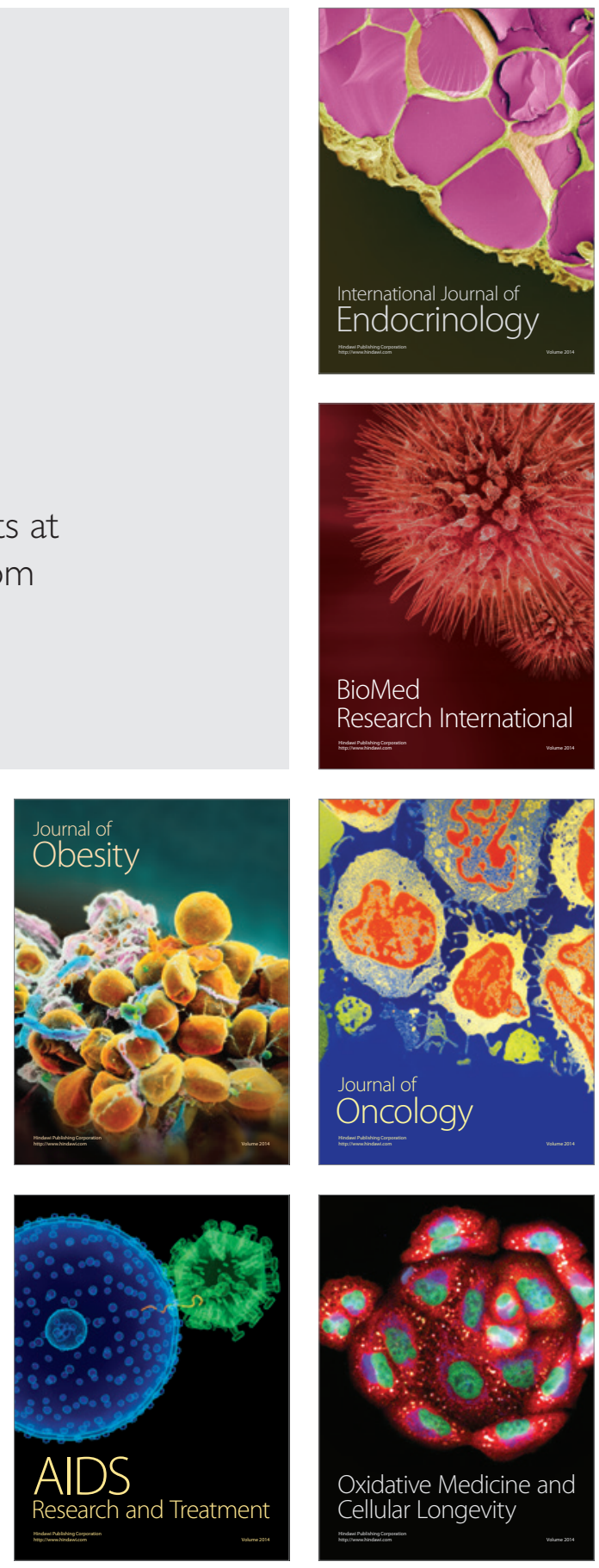